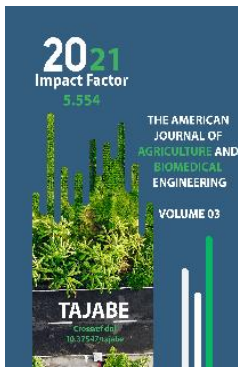

Copyright: Original content from this work may be used under the terms of the creative commons attributes 4.0 licence.

\section{The Current State Of The Use Of Lalmi Crop Land And The Main Directions Of Their Improvement}

Babajanov A.P

Tashkent Institute Of Irrigation And Agricultural Mechanization Engineers, Uzbekistan

Ro'ziboyev S.B.

Tashkent Institute Of Irrigation And Agricultural Mechanization Engineers, Uzbekistan

\title{
ABSTRACT
}

The article analyzes the current state of lalmi crop lands using the methods of variability, mathematical programming and scientific observation, evaluates and develops the ratio of land and crop species to their location, natural-geographic, socio-economic and environmental conditions of these regions.

\section{KEYWORDS}

Lalmi lands, underground, natural moisture, Mountain Ash, barley, sunflower, spices, autumn, farming, water erosion, "other lands".

\section{INTRODUCTION}

It is also important to develop the country's economy in accordance with the current conditions, rational organization of the use of lalmi crop areas, along with irrigated land, ensuring the stability of the system of food production, ensuring the efficiency of the available resources in this region. Therefore, the development and implementation of a 
special system of measures aimed at the rational organization of the use of such crop lands in the Kashkadarya region, where the vast majority of the lalmi crop areas are located, will yield great results in the near future. Bunda depending on the region in which these lalmi crop lands are located, it is better to determine the optimal composition and area of the land and crop species that will be placed in them, based on all aspects.

The land of the crop is located in different regions according to their natural-climatic and economic characteristics. In this regard, it is desirable for each region to determine the specific proportions and areas of the land and crop variety in different variants, as well as to choose the most optimal option, comparing them to each other, placing them on the basis of the optimal solution proposed in this option. Therefore, in this research carried out, the methods of variability, mathematical programming, optimization and scientific observation were used.

\section{MATERIALS AND METHODS}

Kashkadarya region is one of the main regions of the Republic and its region is distinguished from many other regions with its diversity in terms of its natural and geographical structure. In the territory of the region, along with high mountains, it also consists of wide Adriatic, steppes and deserts. In particular, the mountains fall to the West and south-west, and the book-Shahrisabz goes to the wreck, and then to the Adriatic and plains adjoins. The surface of the flat part of the territory is not the same, in different parts of it, Mountains and plateaus are encountered. In the western part of the territory of the region is the Karshi steppe and Oasis. In general, there are several deserts in the territory of the region-this is the Karshi steppe, in the North and North-West is the Karnov, Jom steppes, and in the South-East is the sighting steppes[1]. The land areas of the region are formed in such a complex naturalgeographical conditions and are successfully used in various sectors of the economy today. In particular, in the steppes and oases, as well as in a part of the lands to which they are located, irrigated lands based on artificial irrigation, and in the steppes, Mountainfoothills and mountain-tops, nonirrigated(lalmi) lands based on natural moistening are formed, and today they constitute the basis of regional agriculture. As can be seen from the official data obtained, $6,10-8,0$ percent of the agricultural products grown in vilocht come from the dam to the lands of the lalmi crop[1]. So, it seems that it is also important to organize rational and effective use of lalmi (non-irrigated) lands in the agricultural sector of the region. 
The American Journal of Agriculture and Boimedical Engineering

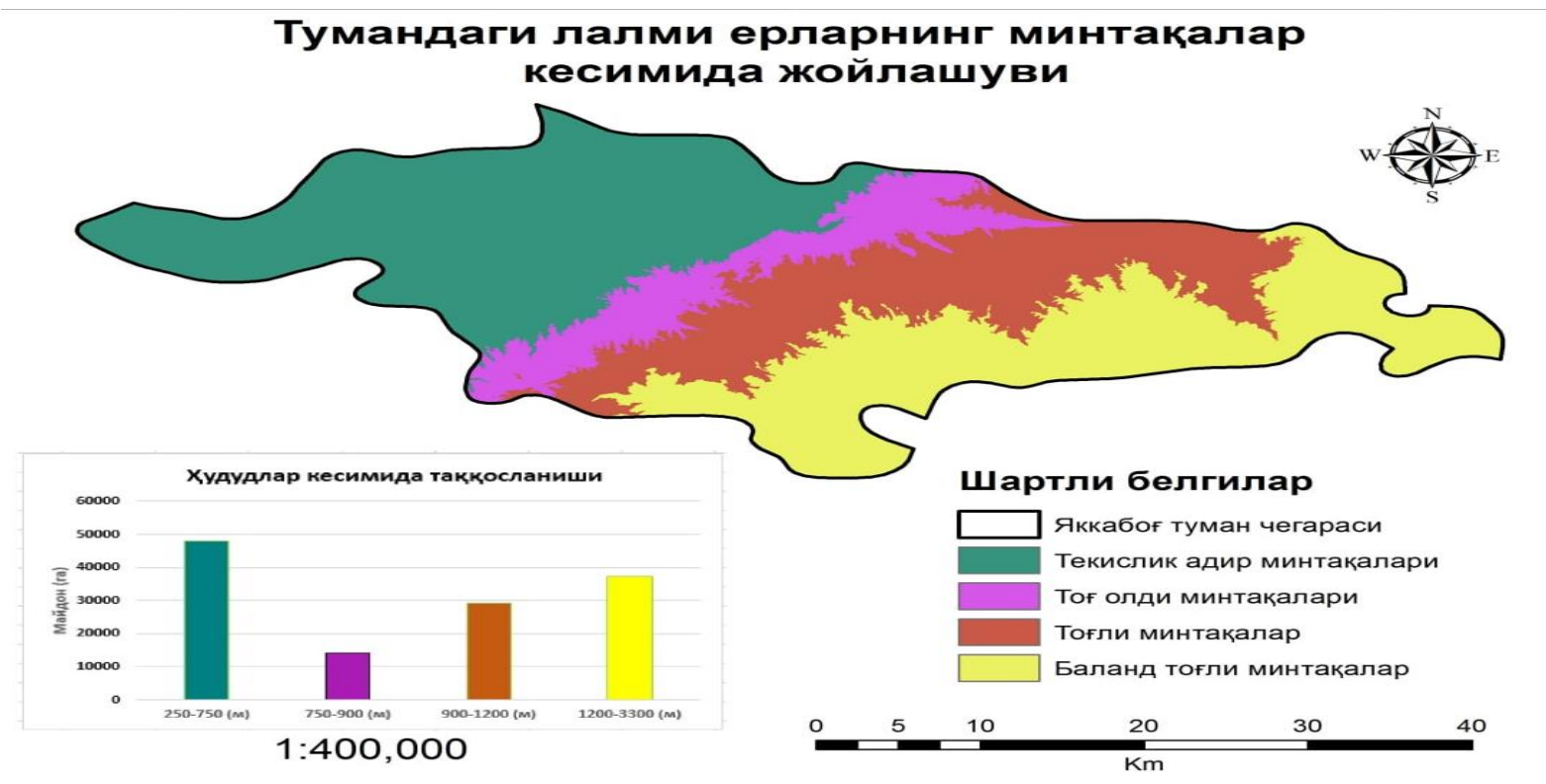

According to the state committee" Davergeodezkadastr", the total land of Kashkadarya region is 2856,8 thousand hectares in the background, according to the state of 01yanvar in 2020. The main part of these areas is the land intended for agricultural purposes.

The study of the current state of agricultural land use shows that 258,7 thousand hectares of the agricultural land used in the region is the land of the lalmi crop (2-table).

1-table

Distribution of total lands of kashkadarya region by main land types. (2020y 01.01)

\begin{tabular}{|c|c|c|c|c|}
\hline \multirow{2}{*}{ T.p } & \multirow{2}{*}{ Асосий ер турлари } & \multirow{2}{*}{$\begin{array}{c}\text { Умуми ер } \\
\text { майдони, минг га }\end{array}$} & \multicolumn{2}{|c|}{ Шундан } \\
\hline & & & Суғориладигани & Суғорилмайдигани \\
\hline 1 & Экин ерлари & 676,1 & 417,4 & 258,7 \\
\hline 2 & Кўп йиллик дарахтзорлар & 39,1 & 36,9 & 2,2 \\
\hline 3 & Бўз ерлар & 21,9 & 4,6 & 17,3 \\
\hline 4 & Яйлов ва пичанзорлар & 1407,1 & 0,1 & 1407,0 \\
\hline 5 & $\begin{array}{l}\text { Жами қишлоқ хўжалик } \\
\text { ерлари }\end{array}$ & 2144,2 & 459,0 & 1595,2 \\
\hline 6 & $\begin{array}{l}\text { Томорқа ерлари ва } \\
\text { боғдорчилик- } \\
\text { сабзавотчилик уюшмалари } \\
\text { ерлари }\end{array}$ & 80,4 & 49,4 & 31,0 \\
\hline
\end{tabular}


The American Journal of Agriculture and Boimedical Engineering (ISSN - 2689-1018)

\begin{tabular}{|c|l|c|c|c|}
\hline 7 & $\begin{array}{l}\text { Мелиоратив қурилиш } \\
\text { холатидаги ерлар }\end{array}$ & 18,8 & 18,8 & - \\
\hline 8 & Уурмонлар & 764,3 & 6,2 & 158,1 \\
\hline 9 & Бошқа ерлар & 449,2 & 449,2 & - \\
\hline & Жами ерлар & 2896,8 & 514,7 & 2342,1 \\
\hline
\end{tabular}

The data from Table 1 show that in the lalmi region of the region, in addition to arable land, there are perennial plantations (2,2 thousand ha) such as hornbeam lands (17,3 thousand ha) and agricultural land types as yaylov and hayzars (1407,0 thousand ha). Here it is necessary to note that Sagittarius and hay have a separate mode of use, so that there is no mention of them. Other agricultural land types, including lalmi arable land (258,7 thousand ha), lalmi perennial darktzors ( 2,2 thousand ha) and lalmi Boz lands (17,3 thousand ha) together (278,2 thousand ha) constitute the lands of the lalmikor agricultural region of the region.

The peculiarities of the climate of the Lalmi region are that precipitation in the region is mainly in the form of strong rains, which tightly clamps the soil and becomes a major obstacle to the growth of crops on Earth[2].

Precipitation occurs mainly in the autumnwinter and early spring periods, and the possibility of weaning a number of crops at a very low vegetation temperature, lalmikor manifests itself in the main feature of farming. M.V. Chetirkin notes that not every nonirrigated peasant will also become a lalmi peasant. Lalmi farming is such a non-irrigated farming, in which a person is a farmer who is able to tolerate large humidification and low vegetation temperatures, which are mainly cultivated in autumn and early spring, and which are subject to vegetation in winter and spring, closer to or in autumn than biological cultivation[2].

It is known that the distribution of precipitation by Regions is associated with the relief of the place itself, that is, the higher the area above sea level, the more abundant the precipitation there is. Alternatively, the degree of supply of precipitation or natural moisture determines the effectiveness of the use of lalmi soils. From this point of view, the territory of lalmi farming is divided into the following regions: plain, plain-adirlik, Foothill and high mountain[2]. Such regions differ from each other not only by the sum of annual precipitation, but also by the amount of humus in the soils distributed in these regions, that is, the production capacity of soils. In Particular, N.V.According to Karpov, the volume of humus in the soils in the plain regions is $1.12 \%$, in the plain-Adirs $1.66 \%$, in the foothills-2.53\%, and in the foothills-4.1\% [4].

According to the results of the abovementioned regionalization, it is possible to see that the lalmi lands of Kashkadarya region are spread in the following regions;

-Mountaineering, spread at an altitude of 12002000 meters above sea level. This zone is provided with natural humidity (annual 
precipitation is $450 \mathrm{~mm}$ and more). In the high mountain range of this region, most of the brown soils are distributed. It is able to give a much better yield than the lalmi lands spread in the region. The main drawback of the territory is the small contours, the use of agricultural machinery is Simply Complicated. The region is located 5 foiz of the land of lalmi crop, that is, 12,98 thousand hectares to this region. There are also perennial plantations that do not irrigate 0,19 thousand hectares in this region. -the foothill region, located at an altitude of 750-900 meters above sea level, with a moisture content (annual precipitation amount 350-450 mm), in this zone mainly spreads in the earthy soils of the hornbeam. This region is considered to be the most favorable region where agricultural crops and perennial plantations have been established. According to official data, 32,9 percent or 85,37 thousand hectares of the region's lalmi crop land were distributed in the region. There are also perennial plantations that do not water 1,01 thousand hectares in this area.

The main disadvantage of the land in the region is that it is prone to water erosion in the region, as well as its use of agricultural techniques with high yields in 25-30 percent is difficult.

- The QIR-adir region, located at an altitude of 450-750 meters above sea level, is semi- supplied with natural moisture (annual precipitation 280-350mm), most of which are spread in typical burlap soils, partially prone to poor washing, and this region is the main region of cultivation of lalmi peasant crops. According to the data obtained, 50 percent of the total lalmi crop land in the region or 129,35 thousand hectares are located in this region. In addition, it will be possible to use agricultural machinery at a high level in all parts of this territory.

- Flatland region, located at an altitude of 230-450 meters above sea level, is not provided with natural humidity (annual precipitation is an average of $250-280 \mathrm{~mm}$ per year), mainly because of the wide distribution of hungry grassy soils. The fertility of these soils is not so high, the amount of humus is on average $0,8-1,2$ foizni. Because of the lack of moisture, agricultural crops are also sown. According to official data obtained, 11,9 percent of the area's lalmi arable land, that is 31,0 thousand hectares, is located on this plain. Based on the above data, we summarize the data on the distribution of the total land of the province of lalmi by regions in the following form. (3-table).

2-table

Қашқадарё вилояти лалми ерларини минтақалар бўйича тақсиланиши (2020 йил 01.01 га)

\begin{tabular}{|l|l|c|c|c|c|}
\hline \multirow{2}{*}{ T.p } & \multirow{2}{*}{ Минтақалар } & Жами майдони, минг га & $\begin{array}{l}\text { Лалми экин } \\
\text { ерлари }\end{array}$ & $\begin{array}{l}\text { Лалми кўп йиллик } \\
\text { дарахтзорлар, } \\
\text { минг га }\end{array}$ & $\begin{array}{l}\text { Бошқа ерлар, } \\
\text { минг га }\end{array}$ \\
\cline { 4 - 6 } & Тоғли & 1053,77 & 12,98 & 0,19 & 1040,6 \\
\hline 2 & Тоғолди & 564,98 & 85,37 & 1,01 & 478,6 \\
\hline
\end{tabular}


The American Journal of Agriculture and Boimedical Engineering

\begin{tabular}{|l|l|c|c|c|c|}
\hline 3 & Қир-адир & 483,74 & 129,35 & 0,59 & 353,8 \\
\hline 4 & Текислик & 239,62 & 31,0 & 0,42 & 208,2 \\
\hline $\begin{array}{l}\text { Вилоят бўйча } \\
\text { жами }\end{array}$ & 2342,1 & 258,7 & 2,2 & 2081,2 \\
\hline
\end{tabular}

From Table 2 it can be seen that a large part of the irrigated land area of the region falls on the region of Qir-adir. Accordingly, the land of the lalmi crop also forms larger areas in this region than others. To the noted "other lands" included yaylov and pichanzors, lalmi Boz lands, forests and others.

Information on the distribution of nonirrigated land, that is, lalmi land by the main land types, depending on the main location regions, can be seen more clearly in the example of the province's Yakkabog' district. (Table 4)

3-table

Distribution of lalmi lands on Yakkabog' district of kashkadarya region to main land types (2020 y. 01.01)

\begin{tabular}{|c|l|c|c|c|c|c|c|}
\hline \multirow{2}{*}{ Т.p } & \multirow{2}{*}{ Минтақалар } & \multirow{2}{*}{$\begin{array}{c}\text { Умумий } \\
\text { майдони }\end{array}$} & $\begin{array}{c}\text { Лалми } \\
\text { экин } \\
\text { ерлари }\end{array}$ & $\begin{array}{c}\text { Кўп йиллик } \\
\text { дарахтзорлар }\end{array}$ & $\begin{array}{c}\text { Бўз } \\
\text { ерлар }\end{array}$ & $\begin{array}{c}\text { Яйлов ва } \\
\text { пичанзорлар }\end{array}$ & $\begin{array}{c}\text { Бошқа } \\
\text { ерлар }\end{array}$ \\
\hline 1 & Тоғли & 19105,3 & 717 & 27,7 & 39,6 & 13302 & 5019 \\
\hline 2 & Тоғолди & 28326,7 & 5013 & 62,4 & 371,28 & 18718 & 4162 \\
\hline 3 & Қир-адир & 17431,9 & 7448 & 9,8 & 822,12 & 7071 & 2081 \\
\hline 4 & Текислик & 4727,1 & 1145 & 4,1 & 93,0 & 2505 & 980 \\
\hline & $\begin{array}{c}\text { Туман буйича } \\
\text { жами }\end{array}$ & 69591 & 14323 & 104 & 1326 & 41596 & 12242 \\
\hline
\end{tabular}

As can be seen from the data from Table 3, the lalmi land in Yakkaboghtuman, which was subjected to research, is also distributed in the above four regions, the majority of the cultivated land is in the region of Qir-adir (52\%), the main part of perennial plantations is in the foothills $(60 \%)$ region, the vast majority of land is in the region of Qir-adir (62\%). 
It is known that lalmi farming is developed to some extent in the province, its main administrative districts. In particular, in addition to the irrigated farming of Yakkabog'tumani, which is subject to the study, there is also lalmi farming, in which the data on the distribution of land under the jurisdiction of the district agricultural enterprises by the main types of land are clearly revealed.

As can be seen from the information in Table 3, 67,3 percent of the total land in the use of the district's agricultural enterprises is the land of lalmi. Bunda, 40,8 per cent of the total arable land of the district, 1.2 per cent of perennial plantations, 100.0 per cent of Boz lands and yaylov and pichanzors, 70,1 per cent of forests, as well as 14.1 per cent of farmland lands constitute lalmi lands. These data also show that the district has a certain share of the land of lalmi in agriculture. At the same time, it should be noted that on the border of the district, the total area of lalmi crop land and burrow land, perennial plantations, most of the yaylov and hay fields are attached to agricultural enterprises, that is, to farmer farms.

Using the above information as well as the characteristics of each region, the results of the studies show that the composition of land and crop species in the existing 14323,0 hectare lalmi crop region on the border of one Yakkabog'tumani is 2: 1: 1 (50\%-pistachios and tonsils, 25\%-grain crops and $25 \%$-oil crops) in the foothill Region. 2:2:1:1 (34\%- pistachio and tonsils, 34,0\%- grain crops, $16 \%$-oil crops and $16 \%$-lalmi melons) in the ratio to be able to achieve high yields.

\section{CONCLUSION}

Based on the above research, it is possible to draw a brief conclusion that the organization of the use of such areas on the basis of the placement of land and crop species in the recommended proportions to the existing lalmi lands in terms of their location allows in the near future to increase their efficiency, create additional 82 new jobs.

\section{REFERENCES}

1. Бабажанов А.Р. Рўзибоев С.Б. Лалми худулардан фойдаланишни ташкил этишда ер ва экин турларини оптималлаштириш. Монография Т.: “ТИҚХММИ”. 2020.- 94 бет.

2. Қўзиев Р.қ., Абдурахмонов Н.Ю, Тошқўзиев М.М., Каримбердиева А.А.,Ўзбекистон Республикаси лалми тупроқларининг унумдорлик даражасини бахолаш бўйича услубий кўрсатма. ТТваАИТИ, 2014 й.

3. Ш.А.Турсунов ва бошқалар “Аграр сиёсат ва озиқ-овқат хавфсизлиги”. Ўкув қўлланма. Т.: “ЎзР Фанлар Академияси Асосий кутубхонаси" босмахонаси нашриёти, 2016. - 2576

4. Карпов Н.В. Краткий очерк природных условий богары Узбекистана. В. сб. Нади. Статей “Полевые культуры на богаре Узбекистана. Т-г” 